\title{
腎腫瘍に対する制癌剤の腎動脈内持続注入療法
}

\author{
增田富士男 \\ 東京慈恵会医科大学泌尿器科教室 佐藤勝 \\ (主往:南武教授) 南 孝明 \\ 南武
}

\section{CONTINUOUS INTRA-ARTERIAL PERFUSION OF RENAL TUMORS WITH CHEMOTHERAPEUTIC AGENTS}

\author{
Fujio Masuda, Masaru Sato, Takaaki Minami and Takeshi Minami \\ Department of Urology, The Jikei University School of Medicine
}

(Director: Prof. T. Minami)

In an effort to enhance the anti-tumor effect of drug therapy and at the same time lessen side effects thereof in the treatment of renal neoplasms, an attempt was made to administer anti-cancer drugs by continuous infusion into the renal artery.

1) Five cases with carcinoma of the renal parenchyma received treatment with an anti-cancer drug infused into the renal artery in a continuous manner through a catheter which beforehand was inserted into the artery and held there after Seldinger technique. The anti-cancer drug used was 5-fluorouracil, which was administered continuously over a 14-day period at a dosage of $500 \mathrm{mg}$ daily, hence in a total dose of $7000 \mathrm{mg}$. Two of these 5 cases were given, in addition to the above medication, 3 doses of $10 \mathrm{mg}$ mitomycin $\mathrm{C}$ by one shot injection into the renal artery.

2) In all of 3 cases with a palpable tumor initially, out of the 5 thus treated, the tumor was found shrunk in size on palpation after therapy. The therapy was also associated with an appreciable reduction in tortuosity of blood vessels as well as in puddling of the contrast agent in the vascular sinuses on renal arteriography in 3 of the 5 cases. Histological examination of the growth following nephrectomy, which was feasible in 4 cases, revealed swelling and irregular boundaries of tumor cells along with karyorrhexis and pyknosis. Further noticeable changes included necrosis, which was seen to be extensive and diffuse in 2 cases and partial in another, and hemorrhage which was predominant in the remaining one case.

3) There was no evidence of systemic side effects involving the digestive tract or the hematopoietic system. The therapeutic procedure, despite of it requiring the catheter to be left in place for a 2week period, was attended, in no instances, by complications such as fever, bleeding, infection and circulatory disturbance of lower extremities. Although slipping off of the catheter from the renal artery into the aorta never occurred in any case, mechanical injury to the renal artery was noticed on the 14 th day in one of early cases.

Being performed with relative ease and with reasonable safety, the therapeutic procedure is considered to be worth trying in properly selected cases.

\section{緒 言}

癌の化学療法は, 1865年 Lissauer ${ }^{14)}$ が亜砒酸カリを 白血病の治療に用いたのが始まりといわれている。最近 に抢ける本治療法の発展は著しく, 新しい制癌制の開 発, 投与方法, 手術あるいは放射線治療との併用などに
ついて, 多くの業績が発表されている.

しかし今日の制癌剤は, 一般にその効果にくらべて副 作用が強い.したがつて薬剤の抗腫瘍効果を高めると同 時に, 全身性傷害を出来るだけ軽減するために, 制癌剤 の局所投与法が考案されるに至つた。局所投与法として 
は，制癌剤を腫瘍組織内一直接注入したり腫瘍組織に接 触させる方法や, 局所潅流療法とともに, 腫瘍の支配動 脈内に制癌剤を直接注入する方法などがある.

Klopp ら ${ }^{1112)}$ は始めて腫瘍支配動脈内にポリエチレン チニーブを挿入し，これを経て Nitrogen mustard をく り返し注入することにより, 重症癌患者10例中 8 例に腫 瘍の縮小をみて扣り, この方法は制癌剤の全身性副作用 が少なく, 薬剤の臨床効果がより強力に発揮されるとの ベている.ささらに Sullivan ら ${ }^{2122)}$ は, 動脈内注入ポン プを用い制癌剤を腫瘍栄養動脈内に持続的に長時間注入 する，いわゆる制癌剤の動脈内持続注入療法を試み, 多

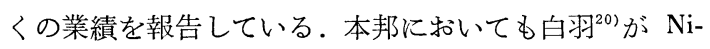
tromin を用い, 動脈内插管による注入を試みて以来, 各 科領域に打いて多くの研究が報告されて打り, 従来にな い著しい抗腫瘍効果が認められている.

腎細胞癌は泌尿器科領域で重要な腫瘍で, その予後は 良好とはいえない. 本症に対する全身的化学療法の効果 は悲観的であり, 制癌剂の局所動脈内注入療法は本邦で は未だ試みられていない。しかし Leiter ら ${ }^{13}$ は腎腫瘍 4 例に対し, 大腿部より経皮的にカテーテルを腎動脈内 に插入固定し, 制癌剤の腎動脈内持続注入療法を試み報 告している. 我々はこの方法にならい, 腎細胞癌患者 5 例に動脈内注入ポンプを用いて 5-Fluorouracil の腎動脈 内持続注入療法を行ない, その効果和よび副作用につい て検討し，いささか知見を得たので報告する.

\section{方 法}

対象. 慈恵医大青戸病院に入院した腎腫瘍患者 5 名に 対し, 本治療法を行なつた。 5 症例とも後に, 組織学的

図 1 腎動脈内カテーテル插入図

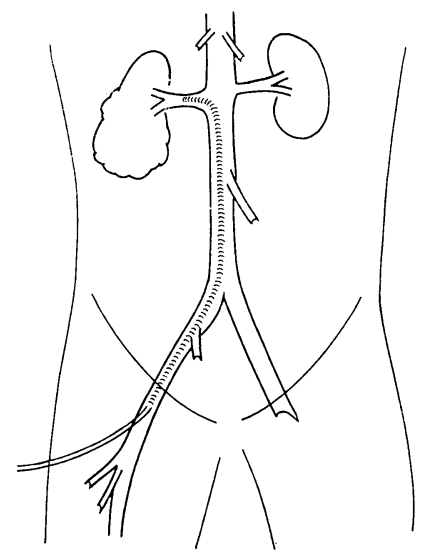

に腎細胞癌と診断されている.

カテーテル挿入法. 動脈内注入療法は腫瘍の栄養動脈 にカテーテルを挿入するため, 通常は手術的処置を要す る 腿部より経皮的にカテーテルを腎動脈に挿入することが 出来る (図 1 ).

まず患者を仰臥位とし, 局所麻酔の後, 舜径勒带の約 $2 \mathrm{~cm}$ 下方で大腿動脈を穿刺する. 穿刺針のマンドリンを 拔いてから guide wire を插入し, ほ济動脈の高さま で荎した後穿刺針を掞去する。ついで guide wire の外 端より，これにかぶせて血管カテーテルを挿入し，カテ ーテルの先端が腎動脈起始部の少し上方に位置するまで すすめてから guide wire を引き抜く。カテーテルは Sweeden, Kifa 社製の green Ödman カテーテルを用い, 先端は熱湯でまげ，尾端に接続金具が取りつけてある. guide wire のため真直にのばされたカテーテルは, wire を除くと本来の形にもどり，弯曲して大動脈壁に向か う.カラーテル先端で大動脈壁をさぐるようにして腎動 脈内に入れる，以上の操作はすべて $\mathrm{X}$ 線透視下または $\mathrm{X}$ 線テレビを用いて行なう.

ついで選択的腎動脈撮影を施行した後カテーテルを大 腿穿刺部皮膚に固定し，血栓形成を予防するため，カテ

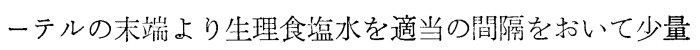
ずつ注入しながら病室にもどし, 直ちに制癌剂の投与を 開始した。

使用制癌剤および注入方法. 制癌剤としては5-Fluorouracil を用い，毎日 $500 \mathrm{mg}$ (第 1 例の及最初の 2 日間は 各1000mg）を投与した。薬剂は $5 \%$ Xylitol 1000 ml に 稀积し、シャープ動脈内注入ポンプを用いて持続的に注 入した、このポンプは $1000 \mathrm{ml}$ を24時間かケて自動的に 注入するよう調節出来る. 5-Fluorouracil の投与期間 は，カテーテルが腎動脈を損傷したため13日間で中止し た第 1 例を除さ，他の 4 例は 14 日間持続注入した，5-Fluorouracil の総量は7000mg (第 1 例のみ $7500 \mathrm{mg}$ ) であ る.また第 4 例と第 5 例の 2 症列は注入第 1 日目, 8 日 目, 14日目の 3 回, 各 Mitomycin C 10mg (総計 $30 \mathrm{mg}$ ) の腎動脈内 one shot 注入を併用した。 な㧤患者は本治 療の期間中, ベットの上で自由に行動することが出来 た.

14日間に亘る注入療法が終了した後, 再び選択的筒動 脈撮影を行ないカテーテルを抜去した。督摘除術はその 後 4 日乃至14日目に施行した.

このような方法で治療を行なうことともに, 注入前お 
よび終了後に血液検查, 肝機能, 腎機能検查を行ない, さらに腫溜の変化, 全身状態および局所の副作用に注意 した。な和副作用防止のための薬剤は特に投与しなかつ た。

\section{成 績}

5 症例の本法による治療成績は表 $1 ， 2$ 亿示した如く である。

腹部触診により腫大した腎を触知し得たものは 5 例中 3 例であつたが，これらはすべて本治療により，腫瘤の 明らかな縮小をみた。

注入前後に行なつた腎動脈撮影像を比較すると，5例 中 3 例に血管蛇行の減少や, Pooling 像の縮小がみられ た。この 3 例中 2 例は腫瘤を触知しなかつたものであ り, 結局 5 例とも臨床的には腫瘍の変化が認められた。

5 例中 4 例は注入後ひきつづいて腎摘除術を施行し た．割面をみると，4例中 1 例に広範囲な壞死融解が， 1 例飞著明な出血巣が，1 例に部分的な壊死掞よび出血 がみられた。残りの 1 例は肉眼的に著変はなかつた。

組織学的にはいずれも腫瘍細胞は膨化し, 胞体境界は みだれ不整になり，核の崩壊や濃縮がみられた。ささらに 2 例は広範囲なびまん性の，1例は部分的な壊死が認め られ, 残りの 1 例は出血が強くみられた。 しかし全例と
もに制癌剤の影響をうけたと思われない生々した腫瘍細 胞も認められた。また 2 例には間質の円形細胞浸潤が著 明であつた。

一方正常腎組織をみると, 一部にくさび状の変性, 壊 死を認める例があつた。

5-Fluorouracil の副作用は消化器系障害が最も多いと いわれている.我々の 5 例は7000mg捛よび7500mgの投与 にも拘らず, 下痢, 食欲不振, 悪心呕吐, 口内炎等の消 化器症状は特に認められなかつた。

赤血球数, 血色素量, 血小板数にも著変はなかつた. 白血球数も $3000 / \mathrm{mm}^{3}$ 以下の減少を示したものはなかつ た.

肝機能については GOT, GPT, アルカリフォスファタ 一ゼ，LDHを測定したが，これらの上昇をみたものは 1 例もなかつた。

注入中 2 例が時々腎部に鈍痛を訴えたが，肉眼的血尿 をみたものはない。

カテーテルを 2 週間插入しておくことに困難はなかつ た. 全例とも 7 日乃至10日頃より穿刺部の皮膚に軽度の 発赤がみられたが，カテーテル抜去後すみやかに消失し た. 穿刺部よりの著しい出血は注入中も，カテーテル抜 去後もみられず，下肢の循環障害も生じなかつた。腎動

\section{表 1 治療成 績 (効 果)}

\begin{tabular}{|c|c|c|c|c|c|c|}
\hline No. & 氏 名 & 年令 & 性 & 腫瘤 & 腎動脈像の変化 & 摘出腎所見 \\
\hline 1 & 田 中 & 71 & $\hat{o}$ & 縮 小 (十) & 蛇行減少 & $\begin{array}{l}\text { 壊死, 細胞変性 } \\
\text { 小円形細胞浸潤 }\end{array}$ \\
\hline 2 & 加 藤 & 76 & $\hat{\delta}$ & 縮 小 $(+)$ & 不＼cjkstart変 & \\
\hline 3 & 村 井 & 51 & $\hat{\sigma}$ & & $\begin{array}{l}\text { pooling 減少 } \\
\text { 造影剤盜流 }\end{array}$ & 壃死, 出血 \\
\hline 4 & 秋 葉 & 67 & 우 & & pooling 減 少 & $\begin{array}{l}\text { 出血, 細胞変性 } \\
\text { 小円形細胞浸潤 }\end{array}$ \\
\hline 5 & 高 崎 & 65 & 우 & 縮 小 $(+)$ & 不 & 壤死, 細胞変性 \\
\hline
\end{tabular}

表 2 治療成 績（副作 用）

\begin{tabular}{|c|c|c|c|c|c|c|c|c|c|c|c|c|c|c|c|c|}
\hline \multirow{2}{*}{ No. } & \multirow{2}{*}{ 氏名 } & \multirow{2}{*}{ 発熱 } & \multirow{2}{*}{ 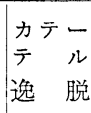 } & \multirow{2}{*}{$\begin{array}{l}\text { 消化器 } \\
\text { 症 状 }\end{array}$} & \multicolumn{2}{|c|}{$\begin{array}{l}\text { 赤血球 } \\
\left(\times 10^{4}\right)\end{array}$} & \multicolumn{2}{|c|}{ 白血球 } & \multicolumn{2}{|c|}{ 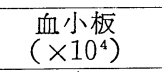 } & \multicolumn{2}{|c|}{$\begin{array}{c}\mathrm{GOT} \\
\text { (単位 } / \mathrm{ml} \text { ) }\end{array}$} & \multicolumn{2}{|c|}{$\begin{array}{c}\mathrm{GPT} P \\
\text { (単位 } / \mathrm{ml} \text { ) }\end{array}$} & \multicolumn{2}{|c|}{$\begin{array}{l}\text { Al. ph. ase } \\
\text { (単位) }\end{array}$} \\
\hline & & & & & 前 & 後 & 前 & 後 & 前 & 後 & 前 & 後 & 前 & 後 & 前 & 後 \\
\hline 1 & 田中 & - & + & - & 299 & 257 & 7800 & 15900 & 21 & 26 & 10 & 18 & 10 & 11 & 1.3 & 1.1 \\
\hline 2 & 加藤 & $\begin{array}{c}+ \\
\text { (肺炎) } \\
\end{array}$ & - & - & 274 & 300 & 3700 & 4500 & 16.9 & 17.0 & 17 & 16 & 5 & 2 & 1.0 & 1.0 \\
\hline 3 & 村井 & - & - & - & 406 & 402 & 4500 & 5200 & 16.8 & 17.5 & 22 & 40 & 9 & 11 & 1.5 & 1.6 \\
\hline 4 & 秋葉 & - & - & - & 336 & 387 & 8500 & 3900 & 25.5 & 21.2 & 5 & 16 & 4 & 12 & 2.0 & 2.6 \\
\hline 5 & 高崎 & - & - & - & 421 & 418 & 6400 & 4400 & 14.6 & 11.9 & 24 & 2 & 5 & 2 & 1.2 & 0.8 \\
\hline
\end{tabular}


脈の栓塞は注入後の腎動脈撮影で特に認められなかつ た。カテーテルの閉塞は注入ポンプの故障により 2 回生 じたが，へパリン加生理食塩水の注入により除去するこ とが出来た.

第 2 例は注入 2 日目より 1 週間に亘り発熱がみられた が，胸部レ線撮影等から気管支肺炎によるものとわかつ た．他の 4 例注熱は認められず，その他の感染症や Sepsis も生じなかつた。

カテーテル先端が腎動脈から大動脈内へ滑り抜けたも のはなからたが，第 1 例は注入14日目に腹痛を強く訴兄 たので直ちに腎動脈撮影を行なつたところ，造影剤の腎 動脈外への溢流がみられたので，腎動脈の損傷と考兄注 入を中止した。

5 例中 1 例は腎摘除後 Stress ulcer 併発して術後 18 日目に死亡した．残りの 4 例中，治療時既に遠隔転移の あつた 2 例は 13 月および 5 カ月目に死亡したが，第 3 例と第 5 例はそれぞれ 15 カ月および 7 カ月の現在生存し ており，著変をみない。

次に 2 症例について治療経過，成績を述べる.

症例 1 . 田中某, 男, 71 才。

昭和 43 年 3 月中旬頃より $5 \sim 6$ 回血尿を認めていた が，同年 7 月 10 日右季肋部腫瘤河気づき， 7 月18日当科 受診, 入院した. 栄養状態は可, 右季肋部に $10.5 \times 10.5$ cmの腫瘤あり．表面は凹凸不平でやや硬く，移動性はわ ずかにみられた。排泄性腎孟撮影，腎シンチグラムで左 腎は正常であるが，右腎は機能がみられず，逆行性腎孟 撮影では右腎孟，腎杯の上方への圧排，変形が認められ た.

7 月30日，上述の方法で経皮的に大腿動脈より右腎動 脈内にカテーテルを挿入し，選択的腎動脈撮影を行なつ たところ, 血管の蛇行, puddling 像あり（図 2 ).腎腫瘍 と確定したのでカテーテルをそのまま留置, 固定し, 5-Fluorouracil の持続注入を開始した. 5-Fluorouracil を

図 3 症例 1 腫瘤の变化

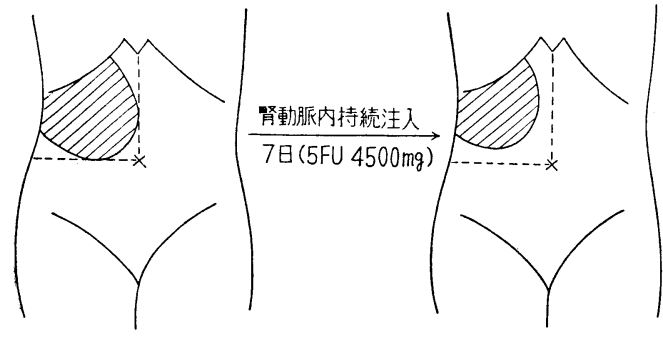

腫瘤 $10.5 \times 10.5 \mathrm{~cm}$

腫瘤 $9.0 \times 8.5 \mathrm{~cm}$
最初の 2 日間は各 $1000 \mathrm{mg} ， そ の$ そ後の 11 日間は連日 500 $\mathrm{mg}$ ，合計7500mgを13日間に亘り投与した。

施行後 7 日目に, 腹部触診上腫瘤は $8.5 \times 9.0 \mathrm{~cm}$ 之縮 小し，硬度もやや軟かくなつた（図 3 ).同時汇行なつた 腎動脈像では腫瘍血管の蛇行の減少がみられた（図 4). 注入 5 日目より時々右季肋部に鈍痛を訴えたが，発熱， カテーテルの閉塞, 穿刺部よりの出血, 下肢の脈搏の異 常はなかつた。

注入14日目，患者は右季肋部痛を強く訴兄，墨心呕吐 を伴なつた，直ちに腎動脈撮影を施行したところ，造影 剤の一部の腎動脈外溢流が認められたので，腎動脈の損 傷と考光注入を中止した，その 4 日後に腎摘除を行なつ たが，留茎周囲にはくるみ大の凝血塊がみられただけで あつた。

施行前血色素 $8.6 \mathrm{~g} / \mathrm{dl}$, 赤血球数 $299 \times 10^{4}$, 白血球 数 7800 , 血小板数 $21.0 \times 10^{4}$, G.O.T. 10 単位 $/ \mathrm{ml}$, G.P.T. 10単位 $/ \mathrm{ml}$, L.D.H. 80.5 単位 $/ \mathrm{ml}$, アルカリフォスファタ 一ゼ 1.3 単位であり，尿検査では蛋白 $30 \mathrm{mg}$, 赤血球は 1 視野に10〜20 コ認められた. 注入後は白血球数が增加し た以外飞藷変なく，5-Fluorouracil による消化器障害も 認められなかつた。

摘出腎の大きさは $15 \times 13 \times 7.5 \mathrm{~cm}$, 重量 $750 \mathrm{~g}$ であつ た。腎実質は僅かに上極にみられただけで大部分が腫瘍 で占められており, 割面では腫瘍の大半が壊死融解して いた (図 5 )。組織学的には clear cell carcinoma であ つたが，壊死巣周辺の腫瘍細胞は膨化し，胞体境界の不 整がみられ，核の濃縮や崩壊も認められた。間質には小 円形細胞浸潤がかなりみられ，石灰化巣も認められた

(図 6 ).

本例は stress ulcer を併発し，術後18日目に死亡し た。

症例 3 . 村井某, 男, 51 才。

昭和 44 年 6 月 5 日無症候性血尿 あり，同 9 日来院し た。一般状態は良好で腎は触知しない，排泄性腎孟撮影 で右腎は正常であるが，左腎では下腎杯の上方への圧 排，変形がみられ，腎シンチグラムでも下極に欠損像が 認められた。左腎動脈像ではこの部に pooling 像ぶあ り，腎腫瘍と診断した（図 7 ）。

直ちに上述の方法で 5-Fluoryuracil を 500mgあて14日 間合計7000mgを持続注入した.

本治療終了時の腎動脈像で pooling 像の縮小と，造影 剤の腎実質内への溢流がみられた（図 8 ).

注入前は血色素 $13.7 \mathrm{~g} / \mathrm{dl}$, 赤血球数 $406 \times 10^{3}$, 白血 
球数 4500 , 血小板数 $16.8 \times 10^{4}$, G.O.T. 22 単位 $/ \mathrm{ml}, \mathrm{G} . P$. T. 9 単位 $/ \mathrm{ml}$, L.D.H. 80 単位 $/ \mathrm{ml}$, アルカリフォスファタ 一ゼ 1.5単位であつたが，注入後もこれ等の值に著㫚な く, 骨髄機能, 肝機能の障害はみられず, 下痢, 悪心呕 吐, 食欲不振等の消化器症状もなかつた。 また注入中疼 痛はなく，血尿も認めず，穿刺部の出血や発熱も又られ なかつた。

注入終了後 5 日目に腎を摘除したが，大きさ $10.5 \times$ $6.5 \times 4.5 \mathrm{~cm}$, 重量 $210 \mathrm{~g}$ で, 下極に $4.0 \times 3.5 \mathrm{~cm}$ の腫瘍 がみられた。割面をみると，腫瘍の下部に壊死尛とこれ を囲んで出血斑がみられた（図 9 ). 組織学的には clear cell carcinoma であり, 腫瘍細胞の変性が認められた （図10）、正常腎組織をみると，〈さび状の梗塞が被膜下 にみられ，これに一致して動脈内膜の肥厚と血栓による 閉塞が認められた（図11）。術後 1 年 3 カ月の現在健康 で, 再発や転移はみられない。

\section{総括ならびに考案}

腎腫瘍に対する制癌㶡の全身的投与の効果は現在のと ころ悲観的である ${ }^{6)}$. 我々の教室の統計でも, 本症の生 存率は化学療法の併用, 非併用群間に差を認めない ${ }^{15)}$.

したがつて薬剤の抗腫瘍効果を高めると同時に，全身性 の副作用を防止するための 1 つの方法として, 腫瘍へ入 る栄養動脈にカテーテルを插入し，局所に高濃度の制癌 剤を注入することが考えられる.

このような新しい投与方法である局所動脈内注入法は

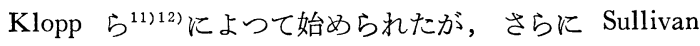
ら ${ }^{21) 22)}$ はポンプを用いて制癌剤を持続的に長時間注入す る，動脈内持続注入療法について報告している. 本邦に おいても外科，耳鼻科等で，従来にない著しい抗腫瘍効 果が認められている(8)16)18)。腎腫瘍に対しては, Leiter ら ${ }^{13)}$ が 4 例に，7 日から12日間本法を行ないその価值に ついてのベている.

動脈への注入方法については, one shot で注入する か持続的に注入するかについて賛否両論がある(2)10). これには使用する制癌剤の種類, 作用機序, 腫瘍の感受 性, 宿主の抵抗力等多くの因子が関与して和り, 直らに 優劣を決めることは困難である. Leiter $ら^{13)}$ は 4 例中 3 例に 5-Fluorouracil を，1 例に Methoterexate を用いた が，我々は long acting で cystostatic な 5-Fluororacil を持続注入した。

5-Fluorouracil は1956年 Duschinsky ら゙より合成 されたピリミジン拮抗性抗腫瘍剤であり, Heidelberger ら 9) を中心としてその基礎的, 臨床的研究が行なわれ,
すぐれた抗腫瘍効果が認められている，腫瘍組織におい ては細胞の分裂に必要な核酸を合成するために，ウラシ ルの利用が正常組織よりもきわめてさかんである ${ }^{17)}$.

5-Fluorouracil はピリミジン塩基のウラシルの 5 の位置 の水素原子 1 個を弗素原子で置換したものであるが，こ れを投与するとウラシルと同じ経路をたどつて核酸合成 のサイクルに入る. そしてウラシルと競合して悪性腫瘍 に選択的に取りこまれ， thymidilate synthetase を抑制し て DNA の生合成を阻害し，すぐれた抗腫瘍效果をあ らわすといわれている9 .ところで各腫瘍細胞は無秩序 に, かつ連続的に分裂を続けるので, すべての腫瘍細胞 に代謝拮抗剤が取りこまれるためには，少なくともすべ ての細胞が 1 回の分裂を終つて 2 度目の分裂期に入るま での期間注入を継続する必要がある.

以上のべた如く, 動脈内持続注入療法は局所にのみ選 択的に高濃度の薬剤を投与することによつて, 副作用の 軽減を図ると同時に，連続的に長時間注入し，すべての 腫瘍細胞に代謝拮抗剤を取りこませ，より大きな抗腫瘍 効果を期待しているわけである.

また第 4 例と第 5 例の 2 症例に Mitomycin C を併用 したが，5-Fluorouracil と Mitomycin C とに相乗作用 があると認められているからである5). しかし Mitomycin C は short acting であり, cystocidal であるため one shot で注入した.

持続注入期間について Leiterら ${ }^{13)}$ は 2 週間までとして おり, 我々も腫瘍細胞の抵抗性の増加, 動注による血管 壁の障害汭を考えて 2 週間としたが，この期間和よび制 癌剤の投与量についてはさらに検討を加えたい.

我々の 5 症例の経験では, 腹部腫瘤を触知し得た 3 例 とも本治療により触診上その綰小をみて扣り, 注入前後 の腎動脈像の上で，5例中 3 例に腫瘍血管の蛇行の減少 や pooling 像の縮小をみている.また 1 例に, 注入終了 後の動脈像で造影剤の腎実質への溢流がみられたが，こ れは造影剤の壊死組織への漏出によるものと考光られ る.

Leiter ら $^{13)}$ は注入後の腎動脈像で腫瘍の大きさは不変 か, 僅かな縮小にすぎないが，血管の蛇行は減少したこ とを認めている．また本治療後腎摘除を行なつた 3 例中 2 例は腫瘍の壊死がみられたが，他の 1 例は肉眼的，顕 微鏡的にも变化は認められなかつたとのべている。

我々の摘出した 4 例の病理学的検査では, 腫瘍細胞の 膨化, 胞体境界の不整, 核の崩壊濃縮, さらに壊死, 出 血がみられた，腎腫瘍は自然壊死がよくみられるから， 
図 2 症例 1 腎動脈レ線像（注入前）

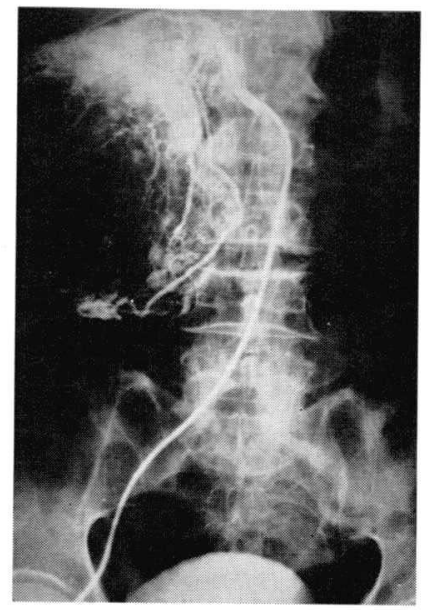

図 5 症例 1 摘出腎割面

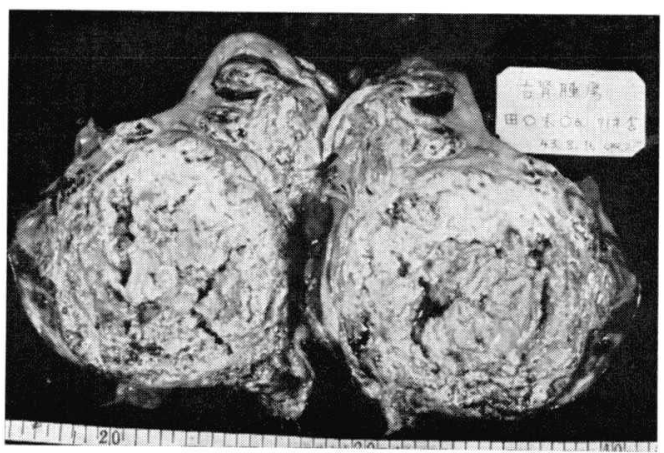

図 7 症例 3 腎動脈レ線像（注入前）

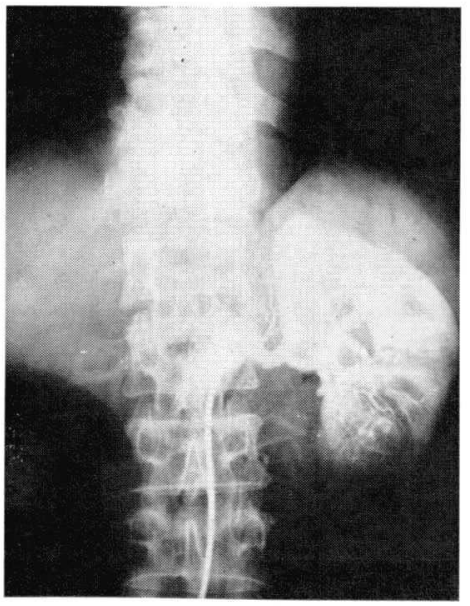

図 4 症例 1 腎動脈レ線像(5-FU 4500mg注入直後)

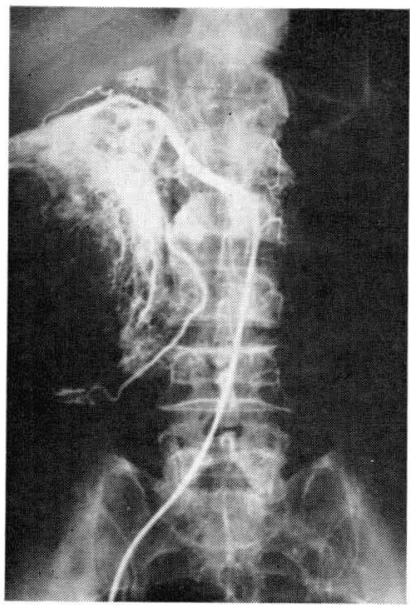

図 6 症例 1 組轼像

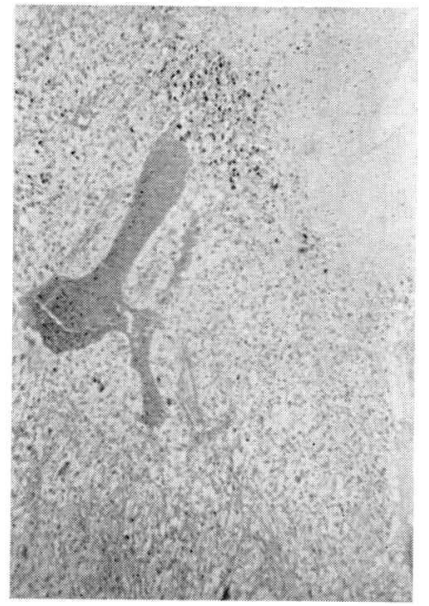

図 8 症例 3 腎動脈 $レ$ 線像 (5-FU 7000mg注入直後)

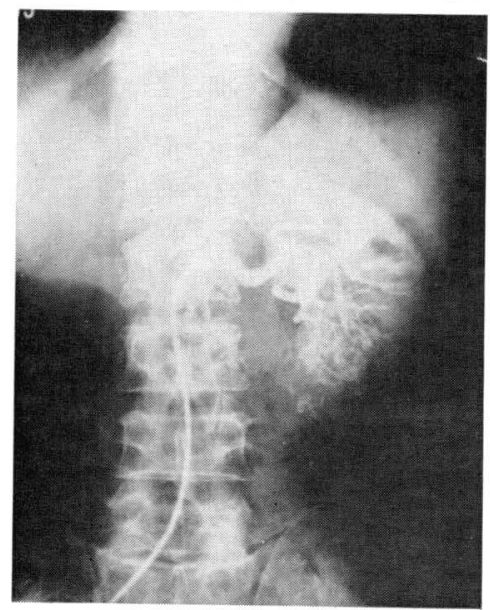


図 9 症例 3 摘出腎割面

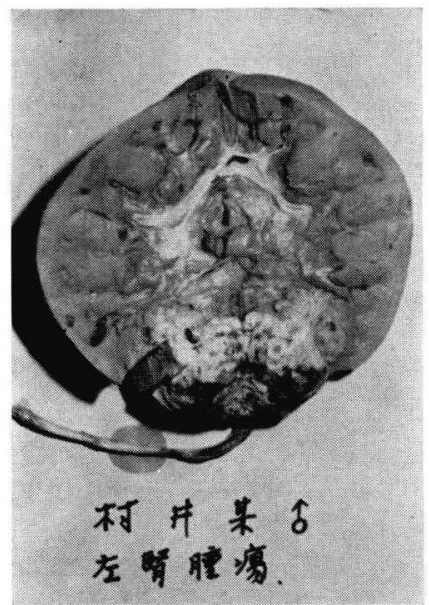

図11症例 3 組織像（2）

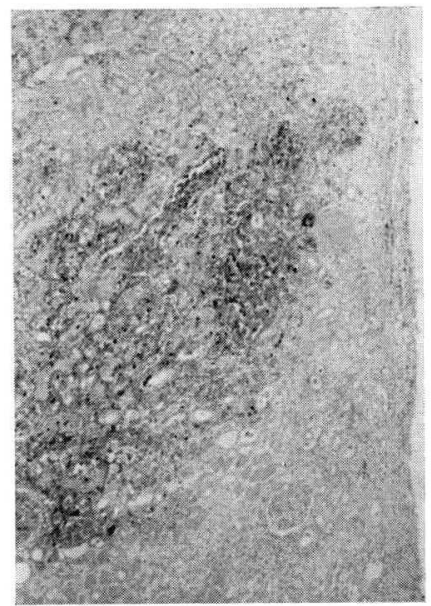

これを直ちに制癌剤の効果とは断定出来ないが，壞死周 用の腫瘍細胞の変性がかなり強いことから制癌剤の作用 が十分に考えられる，一方正常腎組織について，Leiter $ら^{13)}$ は顕微鏡的にも何ら変化がなかつたといつている. 我々の例でも制癌剂自身による変化は特に認められなか つたが，〈さび状の梗塞とこれに一致して動脈内膜の肥 厚と血栓による閉塞をみた例があつた。これは循環障害 によると考えられ，今後な特検討を加えたい．

5-Fluorouracil の副作用としては消化器障害が最も多 く, ついで白血球減少, 血小板減少等の造血采障害がみ られ，さらに脱毛，皮膚炎等の皮膚障害があげられてい、 る1). 我々の症例では7000mg抹よび7500mgの投与にも拘 らず，5-Fluorouracil による胃腸症状はみられず，肝機
図10 症例 3 組織像（1）

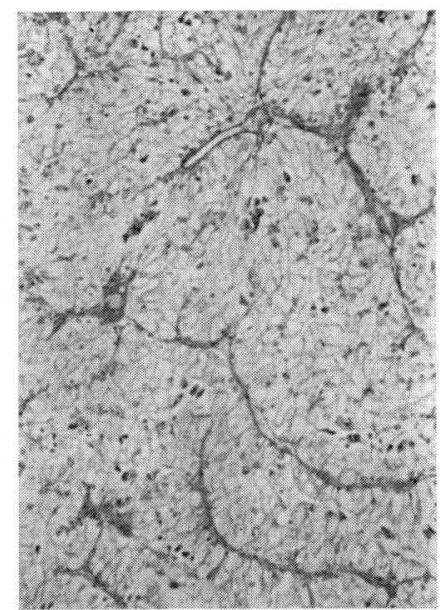

能障害もなかつた. 血色素, 赤血球数, 血小板数も変ら ず, 白血球数が3000以下に減少した例もなかつた. Leiter $ら^{13)}$ の報告でも同様で, 5-Flurouracil が組織と容易 に結合し利用されるためと考えられる。また注入中，第 1 例と第 5 例の 2 症には時々腎部に鈍痛を訴えたが，こ れは壊死せる腫瘍組織への 5-Flurouracil の漏出による と考える人衫るいる.

Leiterら ${ }^{13)}$ は注入開始数日後に，全例とも $101^{\circ}$ 万至 $104^{\circ}$ の発熱を認めているが，我々の例では発熱例はな く，注入による肉眼的血尿もなかつた.

カテーテルを 2 週間持続的に腎動脈内に插入しておく ことに特別の困難はなく, 出血, sepsis, 下肢循環障害等 もなかつた．患者に対して注入中ベット上での行動を自 由にさせたが，カテーテルの先端が腎動脈内より大動脈 へ滑り落ちたものはなかつた. Leiter $ら^{13)}$ も腎動脈にカ テーテルを挿入, 留置しているための合併症は特に認め ておらず，また期間中チニーブの長さ（15〜20フィー ト）の範囲で自由に行動させているが，4例ともとのた めにカテーテルの腎動脈外选脱はない。しかし第 5 例目 で7日目にカテーテルが大動脈内に滑り落ら, そのため 薬剂 (Methotrexate) による高度の白血球減少を生じ, 10日後に死亡したことを報告している. また我々の第 1 例では14日目に腎動脈の損傷がみられたことから，カテ ーテル先端の位置については十分な注意が必要である. このためには常に局所および全身の臨床症状に注意して いると同時に，適時レントゲン撮影をすることにより早 期発見や危険防止が出来る.

カテーテルの閉塞は注入ポンプの故障の際にみられた 
が，へパリン加生理食塩水の注入あるいはカテーテル内 へ wire を挿入して除去することが出来るし, 注入中止 にまで至つたものはなかつた。

予後追跡期間は最短 7 カ月, 最長 1 年 3 カ月にすぎ ず, 症例数も少ないので予後については言及出来ない。 しかし本治療法が，全身投与に比べて癌細胞への制圧作 用が格段に強いことは間違いなく，副作用の軽微なこと る明白である. その上本法は比較的容易に, 且つ安全に 行なえるので, 適応症例を選んで行なら価值ある治療法 と考える。また 5-Fluorouracil に放射線増感作用のある ことより，本法と放射線治療との併用療法も試みてみた い.

\section{結語}

1）5例の腎細胞癌患者に対し, Seldinger 法により 腎動脈内に挿入，固定したカテーテルを通じて，制癌剤 の腎動脈内持続注入療法を行なつた.

2）制癌剂としては 5-Fluorouracil を1日 500mg，14 日間合計7000mg (第 1 例の久 $7500 \mathrm{mg}$ )を, 動脈内注入ポ ンプにより連続的に投与した。 2 症例にはMitomycin C 10mgの腎動脈内 one shot 注入を 3 回宛併用した.

3） 5 例中腫瘤を触知し得た 3 例は，何孔も触診上そ の縮小をみた。腎動脈像では 5 例中 3 例に血管蛇行の減 少, pooling 像の縮小を認めた。

4）本治療後腎を摘除した 4 例では，腫瘍細胞の膨 化，胞体境界の不整，核の崩壊や濃縮がみられた，2例 にはさらに広範囲なびまん性の，1例には部分的な壊死 が認められ，残りの 1 例には出血が強くみられた。

5）消化器および造血器系障害等の全身性副作用はみ られなかつた。 各例にカテーテルを 2 週間留置したが， 発熱, 出血, 感染, 下肢の循環障害はなかつた。 カテー テル先端が腎動脈内より大動脈へ滑り拔けたものはなか つたが，第1例では14日目に腎動脈の損傷が認められ た.

6）本治療法は比較的容易に，且つ安全に行なえるの で，適応症例を選んで行なう価値があると考える。

\section{文献}

1) Ansfield, F.J., Schroeder, J.M. and Currei, A.R.: J.A.M.A., 181, 295, 1962.
2) Cook, J.: Lancet, 1, 25, 1960.

3) Creech, O.J., Krementz, E.T., Ryan, R.F., Reemtsma, K., Elliot, J.L. and Winblad, J.N.: J.A.M.A. 171, 2069, 1959.

4) Duschinsky, R., Pleven, E. and Heideiberger, C.: J. Am. Chem. Soc., 79, 4559, 1957.

5) 藤田 浩, 中山 昇, 沢部孝昭, 内田恒代, 青 木光子, 土田裕子, 木村禧代二 : Chemotherapy, $18,387,1970$.

6) Grabstald, H.: N.Y. Sate J. Med., 64, 2771, 1964.

7) 服部孝雄, 伊藤一二, 三輪 潔, 平田克治, 藤 田浩, 遠藤幸夫 : 癌の臨床, $10,96,1964$.

8) 林一, 成田令博, 斎藤志郎, 山下一郎, 浅野 泰彦, 驚津邦雄, 爪生 惇, 多部田義美, 今井 利広, 大陕 肇, 山本道也, 林 進武, 斉藤基 明, 中久木一乗 : 癌の臨床, $13,875,1967$.

9) Heidelberger, C. and Ansfield, F. J.: Cancer Research, 23, 1226, 1963.

10) 北条慶一: Chemotherapy, 13, 316, 1965.

11) Klopp, C.T., Alford, J.C., Bateman, J., Berry, G.N. and Winship, T.: Ann. Surg., 132, 811, 1950.

12) Klopp, C.T., Bateman, J., Berry, N., Alford, C. and Winship, T.: Cancer Research, 10, 229, 1950.

13) Leiter, E., Edelman, S. and Brendiler, H.: J. Urol., 95, 169, 1966.

14) Lissauer: Berl. Klin. Wchschr.: 2, 402, 1865. (Hall, T.C.: New England J. Med.: 266, 129, 1962 より引用)

15）增田富士男, 南 武, 千野一郎, 町田秷平, 三 乐誠, 小林睦生. 南 孝明: 日癌治療会誌, 5 , $300,1970$.

16) 三浦 健, 石田正統: 外科診療, 10, 23, 1968.

17) Rutman, R.J., Cantarow, A. and Paschkis, K.E.: Cancer Research, 14, 119, 1954.

18）佐藤靖雄, 森田 守, 高橋広臣, 林 進武, 䉆 津邦雄, 安河内浩, 赤沼篤夫 : 日癌治療会誌, 1, 187, 1966.

19) Seldinger, S.I.: Acta Radiol., 39, 368, 1953.

20) 白羽弥右衛門 : 癌の臨床, 2, 534, 1956.

21) Sullivan, R.D., Miller, E. and Sikes, M.P.: Cancer, 12, 1248, 1959.

22) Sullivan, R.D. and Watkins, E., Jr.: Amcr. J. Roentgen., 89, 590, 1963.

（1971年 4 月10日受付，特別掲載） 